\title{
Trans canal Tympanoplasty with Fibrin Glue: An Effective and Simple Strategy to Manage Tympanic Perforations in Modern Otological Surgery
}

\author{
Waleed M Alshehri*iD , Fahad N AL Tamimi, Mohammed T Hazazi, Jose K Cletus and Bandar M AL Qahtani \\ Otolaryngology Department, King Saud Medical City, Saudi Arabia
}

Submission: January 03, 2020; Published: January 13, 2020

*Corresponding author: Waleed M Alshehri, Otolaryngology Department, King Saud Medical City, Riyadh 12746, Saudi Arabia

\begin{abstract}
Tympanic membrane perforation is one of the commonly encountered clinical complications by an otolaryngologist or an otologist. Although various management strategies and surgical techniques have been described in literature to restore the normal anatomical function of the tympanic membrane, limited studies have reported the use of fibrin glue in routine clinical practice. This case series shows that the trans canal with fibrin glue use is less painful and effective for the post-operative recovery of patients with tympanic membrane perforation.

Keywords: Tympanoplasty; Sealant; Fibrin; Graft
\end{abstract}

\section{Introduction}

Fibrin has an essential role in wound healing. It has hemostatic effects, induces cellular response to wound damage by forming fibrin strands, which eventually builds a matrix, and assists in neovascularization and fibroblast proliferation [1]. Staindl [2] introduced the potential use of fibrin tissue adhesive in otorhinolaryngological surgeries; Tidrick \& Warner [3] first used fibrinogen and thrombin as tissue adhesives in otorhinolaryngological procedures. Since then, use of fibrin sealant has been popular in both otological and neuro-otological procedures [4-6]. Other materials used in end aural techniques to simplify tympanoplasty include fat [7], micropore tape $[8,9]$, atelocollagen [10], cellophane sheet [11], etc. In the past 2 years, a total of 50 tympanoplasty surgeries have been performed using fibrin glue at our center. Using an end aural approach provides the added advantage of scarless results for patients.

\section{Case Presentation}

Fifty patients presented to the outpatient clinic in the past 2 years with complaints of decreased hearing or tympanic perforation and sought surgical treatment. After obtaining complete patient history, patients underwent full head and neck examination, otological assessment with pure tone audiometry (PTA) was performed to determine the type of hearing loss. Our sample selection was based on the perforation size (preferably small), and on the type and degree of air bone gap in PTA.
Cases with simple dry perforations and those without cholesteatoma were indicated for simple underlay myringoplasty. The exclusion criteria were the presence of wet ear, cholesteatoma, or large tympanic perforation. An end aural approach was used to gently clean any debris, with subsequent refreshing of the perforation margin using a needle. A vasoconstrictive pack was used to achieve a bloodless field while harvesting the tragal cartilage; at this point, the fibrin glue is prepared for application. A sizer is placed to measure the size of cartilage needed; thereafter, a gel foam is placed as an underlay and the cartilage graft is placed just above it. The fibrin sealant is then injected all around the perforated area to stabilize the graft and to provide a tight seal layer; subsequently, the gel foam application is repeated. The final step involves applying a cotton ball soaked with fusidic acid ointment $20 \mathrm{mg} / \mathrm{g}$ to plug the ear canal. The patient is discharged on the same day with instructions and follow up in outpatient department.

\section{Results}

Of the 50 cases that underwent surgery for tympanic perforation repair, the surgery was successful in 47 cases. At postoperative day 14 follow-up, remnants of the gel foam pack were noted inside the ear canal along with intact graft. At postoperative one-month follow-up, the air bone gap showed improvement (Figures $1 \& 2$ ); the surface of the graft showed angiogenesis and 


\section{Global Journal of Otolaryngology}

epithelization (Figure 3). Six months postoperatively, the eardrum was epithelialized completely (Figure 4). The rate of closure of the

\section{tympanic perforation was $94 \%$ after the initial attempt.}
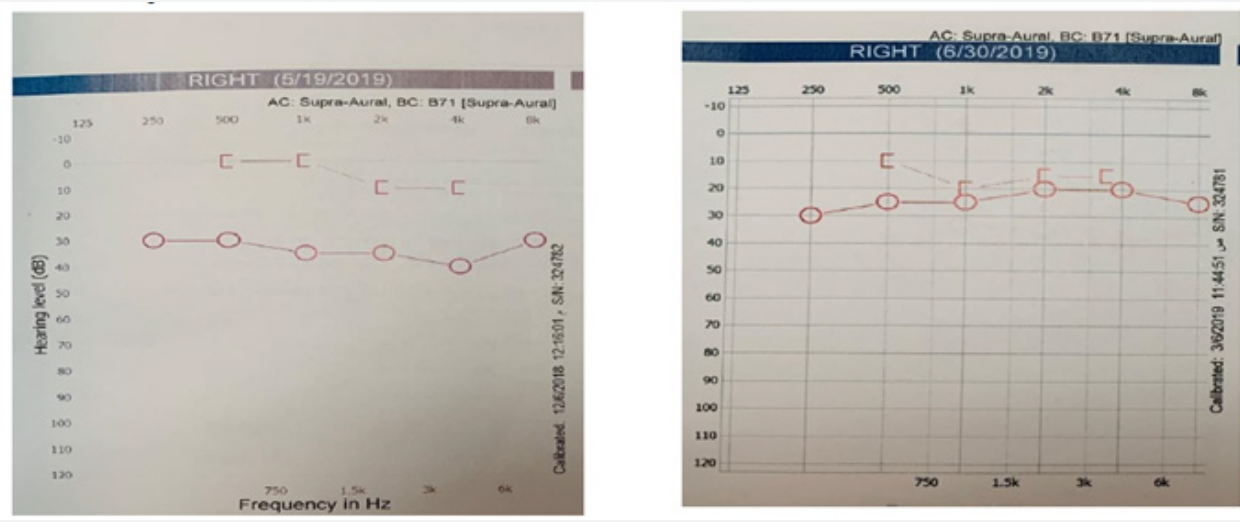

Figure 1: Preoperative and postoperative pure tone audiometry results.
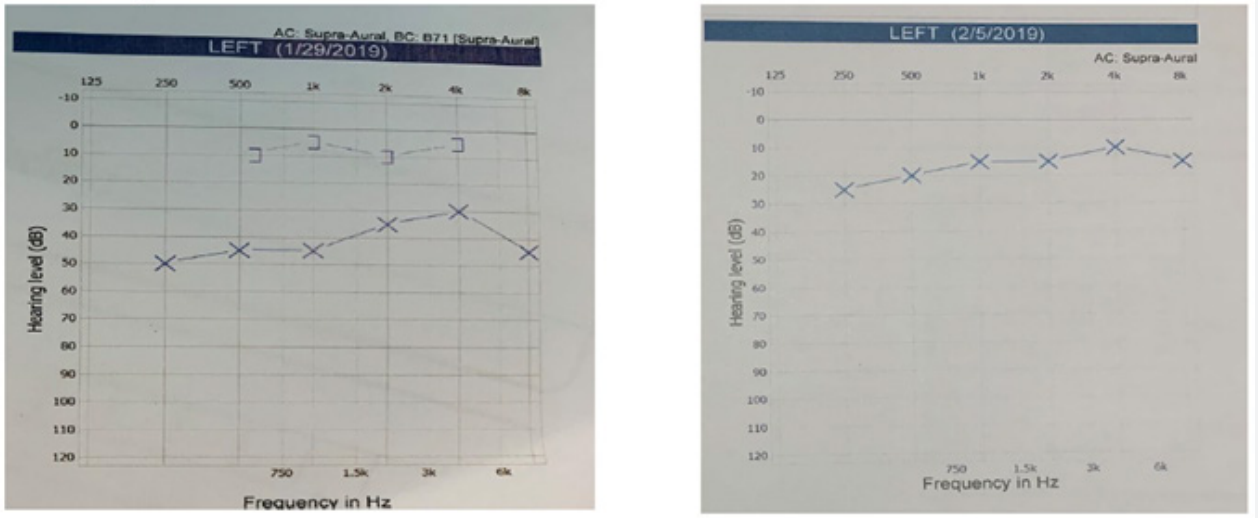

Figure 2: Preoperative and postoperative pure tone audiometry results.

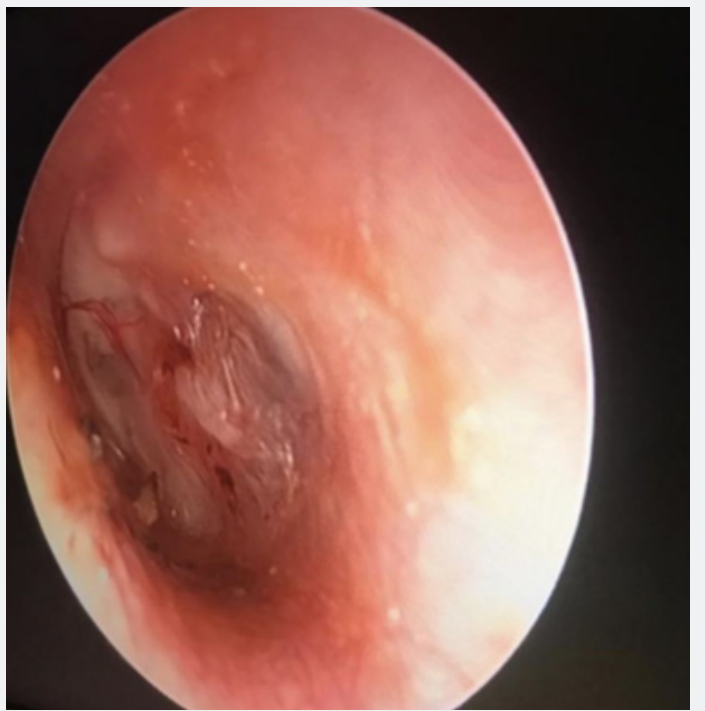

Figure 3: Postoperative 2-month image of the tympanic membrane.

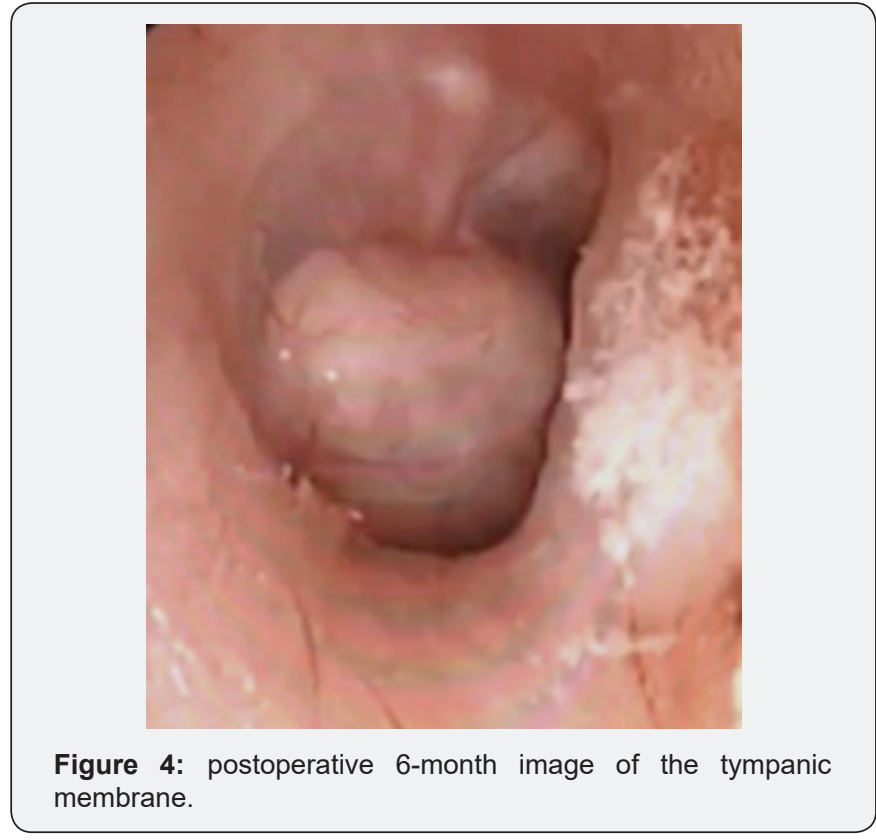
membrane. 


\section{Discussion}

With recent advances in the field of otological surgery both surgeons and patients expect reasonable improvement of hearing postoperatively [12]. Therefore, recently, many otologists have perfected various surgical techniques that uses auto-, homo-, and allo-implants [13]; in all these approaches, an adhesive agent with stable characteristics and biocompatibility is frequently used to stabilize and rejoin various anatomical structures. For trans canal closure of a tympanic perforation in chronic otitis media, Yuasa [14], in 1989, developed a simple underlay myringoplasty with fibrin glue.

The simple underlay myringoplasty has been widely performed in Japan over the last 15 years because of its high success rate for tympanic membrane closure and extremely low risk of sensorineural hearing loss [15-17]. In our study, we aimed for minimal invasiveness and optimal outcome. The postoperative surgical outcome and satisfaction in all patients were assessed at 2 weeks, 1 month, and 6 months of follow-up.

All patient had painless recovery and could regain their daily activities within a few days. High success rate, ability for scarless surgery, and decrease risk of hematoma and infection were other reasons for considering this surgical approach over other established techniques for tympanic membrane perforation repair such as post auricular approach. Additionally, this surgical method had no complications.

\section{Conclusion}

In conclusion, trans canal tympanoplasty is a simple, effective, and minimally invasive procedure which uses fibrin glue to repair tympanic perforations and has a high rate of success, with no complications. This method may provide shorter operative time.

\section{Limitations}

We were unable to blind the physician investigator or the patient in this study.

\section{References}

1. H J Aho, J Viljanto, J Raekallo, L J Pelliniemi (1983) “Ultra-structural characteristics of cells in human wound collected by Cellstic device." Journal of Surgical Research 35(6): 498-506.
2. O Staindl (1977) “Die Saunders-Plastik biem Morbus Osler unter Verwendung hochkonzentrierten humanen Fibrinogens als Gewebekleber." Laryngologie Rhinologie 56: 887.

3. R T Tidrick, E D Warner (1944) "Fibrin fixation of skin transplants." Surgery 15(1): 90-95.

4. G Babighian (1982) "L'impiego del Tissucol nella chirurgia ricostruttiva dell'orecchio medio." Orte Traum oggi 2:1-4.

5. J Marquet (1985) "Fibrin glue in tympanoplasty." Otology and Neurotology 6(1): 28-30.

6. O Staindl (1979) "Tissue adhesion with highly concentrated human fibrinogen in otolaryngology." Annals of Otology, Rhinology \& Laryngology 88(3): 413-418.

7. P S Camnitz, W S Bost (1985) “Traumatic perforations of the tympanic membrane: early closure with paper tape patching." OtolaryngologyHead and Neck Surgery 93(2): 220-223.

8. H Saito, Y Kazama, Y Yazawa (1990) "Simple maneuver for closing traumatic eardrum perforation by micropore strip tape patching." The American Journal of Otolaryngology 11(6): 427-430.

9. J C Ringenberg (1978) "Closure of tympanic membrane perforations by the use of fat." The Laryngoscope 88(6): 982-993.

10. T Sakota, A Shibano, Y Saitoh, Y Dake, H Sogo, et al. (2000) "An office technique without the use of fibrin glue [in Japanese]." Nihon Jibiinnkoka Gakkai Kaiho (Tokyo) 103(7): 836-839.

11.J E Amadasum (2002) "An observational study of the management of traumatic tympanic membrane perforation." The Journal of Laryngology \& Otology 116(3): 181-184.

12. J V Hough (1970) "Tympanoplasty with interior fascial graft technique and ossicular reconstruction." Laryngoscope 80(9): 1385-1413.

13. C Zini, M Sanna, S Bacciu (1978) "Une methode alternative aux homogreffes: heterogreffes timpaniques moulees." Paris 451.

14. R Yuasa, S Saijo, Y Tomioka, C Kusakari, S Kakehata, et al. (1989) "Office closure of eardrum perforation with fibrin glue [in Japanese]." Otolaryngology-Head and Neck Surgery (Tokyo) 61: 1117-1122.

15. R Yuasa, M Suetake, Y Kaneko and J Kanbayashi "A new simple myringoplasty with fibrin glue." In: Yanagihara N, Suzuki J, eds Transplants and Implants in Otology, Amsterdam: Kugler Publications 207-210.

16. R Yuasa (1997) "A new underlay myringoplasty with use of fibrin glue as minimally invasive surgery." In: Sanna M, ed Cholesteatoma and Mastoid Surgery Rome: CIC Internazionali 854-858.

17. M Sakagami, Y Mishiro, K Tsuzuki, T Seo, M Sone (2000) “Bilateral same day surgery for bilateral perforated chronic otitis media." Auris Nasus Larynx 27(1): 35-38. 
(C) This work is licensed under Creative

\section{Your next submission with Juniper Publishers} will reach you the below assets

- Quality Editorial service

- Swift Peer Review

- Reprints availability

- E-prints Service

- Manuscript Podcast for convenient understanding

- Global attainment for your research

- Manuscript accessibility in different formats

( Pdf, E-pub, Full Text, Audio)

- Unceasing customer service

Track the below URL for one-step submission https://juniperpublishers.com/online-submission.php 